research is to have strong basic research, so I strongly support the idea that the two should be integrated," he says. Lærum defends the government's decision to appoint individuals representing a wide range of social interests to the board of the new council. "The thinking behind this is that the research councils should serve society, and that the make-up of the members of the board should therefore reflect society."
But even Laerum admits that there are still many details to be resolved before the new arrangements are put into place - for example, how much control other ministries are likely to be able to exert over the individual sub-councils. Meanwhile, the academic community is reserving its judgement: while the idea of a more streamlined system has been gencrally welcomed, approval is mixed with caution that only time will dissolve.

\title{
Norway's universities challenged
}

NORWAY'S universities are bursting at the seams. The government's simultaneous desire to increase the knowledge and skills of its population, and at the same time keep unemployment levels as low as possible, has encouraged it to support a massive expansion of undergraduate places, which rose from 102,000 in 1988 to 140,000 in 1991. Each of Norway's four universities - in Oslo, Bergen, Trondheim and Troms $\varnothing$ - has grown rapidly over the past decade, as have its six university-level colleges.

The explosion in demand has been a mixed blessing for the universities themselves - and in particular for university scientists. Many of the new jobs have gone to create new positions in science and engineering faculties. According to official statistics, the research budgets of the universities have increased substantially as a result, as half of the salaries of university scientists are supposed to cover the time they spend on research. But often the additional funds needed in practice to carry out such research have not materialized.

Pressure on resources resulting from the rapid growth has coincided with an increased concern over ways of raising the quality of research output. These two trends have encouraged the government, despite being dominated by the Labour Party, to modify some of the more egalitarian principles that have dominated the distribution of research funds in the past.

In particular, the general principle that all university scientists receive an equitable sharc of a university's research money is slowly giving way to increased selectivity in the allocation of resources. "We have now decided that in universities, there should be more money for the more productive groups," says Tore $\mathrm{Ol}$ sen of the Ministry of Education, Science and the Church. "For example, if a particular university research group produces more PhD students, we have decided that the group should get a larger share of the money going to that university."

In a similar vein, the Norwegian Research Council for Science and the Huma- nities (NAVF) has, for the past few years, been allocating block grants to research. Both developments represent a significant shift from egalitarian to élitist principles. "That movement has much support from the government, and I think that the support is widespread in the community at large," says Olsen.

The universities themselves have agreed to explore ways of creating "centres of competence", accepting a mutual division of labour between institutions. These centres will be linked together as the nodes of an integrated higher education system, dubbed 'Network Norway'.

\section{Resisting the northern drift}

To move or not to move? That is the dilemma facing the Norwegian government over the fate of the Polar Institute in Oslo, one of the country's leading research institutions for Arctic research and a key participant in current debates over the fate of the world's polar regions.

The institute has been located in the capital since it was founded near the beginning of the century. As on numerous occasions since then, the government is under strong pressure to move the institute up north, possibly to the city of Tromsø.

Not surprisingly, the University of Tromsø (see next page) has been an enthusiastic advocate of the institute's suggested move, arguing that the Polar Institute would form a natural part of its efforts to become a national and international centre for Arctic research.

Resistance to any move is, however, strong among the institute's scientists. According to a recent survey, fewer than five out of a total staff of one hundred said they would be prepared to move up north. Job and housing shortages in the capital that had previously justified the government's efforts to decentralize its activities no longer exist in a period of rising unemployment and falling house values. "We disagree strongly with the proposal that we should move up to
Closer administrative ties between the universities will be backed up by a complex system of electronic linkages and modern data communications technology.

On the political front, the universities, which have traditionally been fiercely independent of each other, have now joined forces to a create a new body, the Norwegian Council of Universities. "We have achieved far better coordination than existed four years ago, and having one university council will make it easier to deal with one research council", says Ole Didrik Larum, professor of medicine and rector of the University of Trondheim, who sits on both bodies and provides a link between them.

Many university scientists have welcomed the concentration of funding. "We are not rolling in money, but we are certainly better off than we were before", says Pers Anderson, professor of brain research at the University of Oslo, and one of the recipients of extra funding under the new block grants scheme. "Already we see a flow of activities, such as being able to send young researchers to international meetings, that we would not have been able to achieve with the new money."
Tromsø, and are not prepared to go along with it", says the institute's director, Orits Land.

Tore Vorren, chairman of the Roald Amundsen Centre for Arctic Research at the University of Tromsø, disputes the argument that Tromsø is too far from Oslo for effective interaction with government officials. "We have come a long way with telecommunications, and do not think that there would be a problem with that."

According to Land, however, the key role played by the institute in advising government departments on Arctic policy makes it essential that it remains physically close to the centre of power. It is also important, he says, that the research activities of the institute should not - as some have proposed - be split from the advisory role that it provides to government departments. "We feel that our advice to government should be directly based on our practical experience," he says.

The government itself is divided on the issue. Departments that rely heavily on advice from the institute want it to stay in Oslo. Others, more sensitive to the pressure of regional demands, favour devolution. A final decision, which many now believe will indeed involve splitting the institute into two, is expected in the next few weeks. 